\title{
THE PATHOGENESIS OF CHRONIC HAEMOPHILIC ARTHROPATHY
}

\author{
HAIM STEIN, ROBERT B. DUTHIE \\ From the Nuffield Department of Orthopaedic Surgery, University of Oxford
}

\begin{abstract}
Specimens of tissue from haemophilic synovium and articular cartilage were collected from 39 patients during reconstructive surgery. They were studied by histochemistry, electron microscopy and microprobe analysis. The detailed findings are presented and discussed. It is suggested that haemophilic arthropathy is the result of a number of mechanisms affecting the synovial lining which becomes progressively fibrotic and the hyaline cartilage which disintegrates and is eventually lost. Mechanical and chemical processes cause degeneration of cells but enzymatic processes appear to be primarily responsible for the degradation of the matrix of the articular cartilage.
\end{abstract}

Haemophilia is a hereditary bleeding diathesis due to partial or complete absence of antihaemophilic globulin (factor VIII). It affects males, but is genetically transmitted through apparently healthy females as a sex-linked recessive characteristic. Its complications have plagued mankind for centuries, and were described in the Babylonian Talmud, written between the second and fifth century AD.

The high incidence of joint involvement in haemophilia was recognised early. Arthritis associated with excessive bleeding was described in 1674 by Philip

Table I. Source of biopsy material

\begin{tabular}{|c|c|c|}
\hline \multicolumn{2}{|c|}{ Joint } & Surgical procedure \\
\hline Hip & 15 & $\begin{array}{l}1 \text { cup arthroplasty } \\
14 \text { total joint replacements }\end{array}$ \\
\hline Knee & 21 & $\begin{array}{l}3 \text { patellectomies } \\
8 \text { arthrodeses } \\
5 \text { synovectomies } \\
5 \text { meniscectomies }\end{array}$ \\
\hline Ankle & 6 & arthrodeses \\
\hline Foot & 1 & wedge tarsectomy \\
\hline Wrist & 1 & carpectomy \\
\hline
\end{tabular}

Hochstetter (Bulloch and Fildes 1912), but it was Volkmann who, in 1868 , stated that " the manifestations of haemophilia and scurvy were often localised to joints". The classical description of haemophilic arthropathy was given by König in 1892, and since then it has been recognised that recurrent intra-articular haemorrhages are the hallmark of this diathesis. The affected joints are normal before bleeding occurs (Key 1932; De Palma and Cotler 1956) but degenerative changes develop gradually as the result of repeated intraarticular haemorrhages until the clinical picture of chronic haemophilic arthropathy becomes apparent.

Intra-articular haemorrhages affect haemophilic patients early in life and only a few reach adulthood with normal joints (Thomas 1936; Driessen 1973). The degree of joint degeneration is directly related to the severity of deficiency of the clotting factor (Hoaglund 1967). Patients with factor VIII levels above one per cent rarely present with spontaneous haemarthroses (Duthie and Rizza 1975). The evolution of this unique arthropathy in man is the subject of the present study.

\section{MATERIAL AND METHODS}

Forty-four tissue specimens of synovium and articular cartilage, collected from 39 patients during reconstructive surgery for chronic hae mophilic arthropathy, were studied. Five patients had two biopsies taken, each from a different joint (Table I). Articular cartilage from five femoral heads, removed for high intracapsular fractures of the neck, served as controls for histochemical staining.

Histology. The tissues removed at operation were fixed in 10 per cent buffered formalin ( 10 millilitres of formaldehyde, 90 millilitres of water and one gram of sodium barbitone), embedded in filtered wax, and sections of six-micrometre thickness were cut. These were then mounted on slides coated with albumin, dried at 60 degrees Celsius for one hour, and stained with haematoxylin and eosin.

Histochemistry. The dry six-micrometre sections of synovium and articular cartilage were separately stained with Perls' reagent for haemosiderin; and 0.3 per cent alcian blue in 3 per cent acetic acid with 0.5 molar and 0.7 molar concentrations of magnesium chloride $\left(\mathrm{MgCl}_{2}\right)$ to demonstrate glycosaminoglycans. Sections were viewed and photographed under the light microscope.

Electron microscopy. Specimens of synovium and articular cartilage were cut into small pieces, 0.5 millimetre long and 2-3 millimetres wide, secured by two 27 -gauge needles to a piece of cardboard with the articular surface upwards for orientation, and immediately fixed in cold 3 per cent gluteraldehyde buffered with $0.1 \mathrm{M}$ cacodylate. The

H. Stein, MD, DPhil, Senior Lecturer in Orthopaedic Surgery, Hadassah University Hospital, P.O. Box 12000,91120 Jerusalem, Israel. R. B. Duthie, MA, ChM, FRCS Ed, FRCS, Nuffield Professor of Orthopaedic Surgery, Nuffield Orthopaedic Centre, Headington, Oxford OX3 7LD, England.

Requests for reprints should be sent to Dr H. Stein.

(1) 1981 British Editorial Society of Bone and Joint Surgery 0301-620X/81/4105-0601 \$2.00 
sections were viewed and photographed using a Jeol JEM-T8 electron microscope, at an accelerating voltage of 60 kiloelectronvolts.

Electron microscopic microprobe analysis (EMMA-4). Microprobe analysis is an application of $\mathrm{x}$-ray microscopy. It is based on the direct excitation of $x$-rays in the investigated specimens by a fine focal spot of electrons, the electron probe, and was independently described in 1951 by Castaing and in 1953 by Borovskii (Cosslett and Nixon 1960). The simplicity of the characteristic $x$-ray spectrum makes it possible to differentiate between near neighbours in the periodic table, and this spectrum is visualised by coupling a television scanning system to the emission micro-analysis (Cosslett and Nixon 1960). Elementary micro-analysis in biological specimens has thus become practicable (Stein et al. 1976). With this method, intracellular iron deposits in specimens of haemophilic synovium and cartilage were unequivocally identified and localised using an EMMA-4 analyser.

Sections for microprobe analysis, 100-150 nanometres thick ("gold") were put onto Formvar, lettered, 100-mesh grids. They were left unstained, and were first viewed and photographed by transmission electron microscopy. The sections which showed electron-dense cytoplasmic inclusion bodies were then coated with carbon and submitted to microprobe analysis. Areas selected for analysis were relocated on lettered grids with the objective aperture in place.

Similar sections were mounted on copper, nickel and titanium grids, so that interference from the metal grid on microprobe analysis could be identified against the readings from comparable biological species

Surgical biopsies of synovial tissues from the knees of four patients (two affected by rheumatoid arthritis and two who underwent meniscectomies) were also submitted to microprobe analysis, to serve as controls.

\section{RESULTS}

\section{Histology}

Synovial membrane. The patients were subdivided into age groups and biopsies taken from the same site were compared in order to correlate the morphological picture with the chronological age (Table II). In the age group 11 to 19 years, the synovium showed marked villous proliferations (Fig. 1), but this feature disappeared, being absent in the age groups 20 to 29 years, while all the patients over the age of 30 years had a conspicuously flat synovium with a well-preserved lining layer, one to three cells thick. The synovium was hyperaemic in the younger age groups (Fig. 1). As a rule,
Table II. Age distribution of investigated patients

\begin{tabular}{|l|l|l|}
\hline \multirow{2}{*}{\multicolumn{1}{|c|}{ Site }} & \multicolumn{2}{c|}{ Age (years) } \\
\cline { 2 - 3 } & Mean & Range \\
\hline Hip (total hip replacement) & 41.5 & $19-65$ \\
Knee (patellectomy) & 29.3 & $22-43$ \\
Knee (arthrodesis) & 32 & $14-53$ \\
Knee (synovectomy) & 20.5 & $11-27$ \\
Knee (meniscectomy) & 31.5 & $27-35$ \\
Ankle (arthrodesis) & 25.4 & $22-36$ \\
\hline
\end{tabular}

the blood vessels did not have a thickened hyperplastic wall, although exceptions could be found. Many of them were occluded by fresh and old thrombi.

Fibrosis of varying degrees affected the subsynovial tissue (Fig. 2). It was considerably less extensive in villi compared to adjacent areas of the synovial membrane. In some cases, this fibrosis had penetrated, disrupted and subsequently replaced the layer lining the joint. In knees, the degree of fibrosis varied. The synovium lining the suprapatellar pouch formed substantial folds, but the subsynovial layer was much less fibrotic in comparison to the synovium of the infrapatellar fat pad and medial joint capsule. Biopsies taken from the lining tissues of hips and ankles generally showed extensive fibrosis of synovial lining tissues, displaying the same pattern as in the knee.

Lining cells of the synovial villi and folds were heavily loaded with haemosiderin (Fig. 1). In comparison, the adjacent subsynovial layers were almost totally devoid of such deposits (Figs 1 and 2). Discrete inflammatory infiltrates were found around deep-seated synovial vessels and adjacent to subsynovial haemosiderin deposits (Fig. 3).

Articular cartilage. Many areas of articular surfaces were denuded of cartilage, exposing sclerotic and eburnated

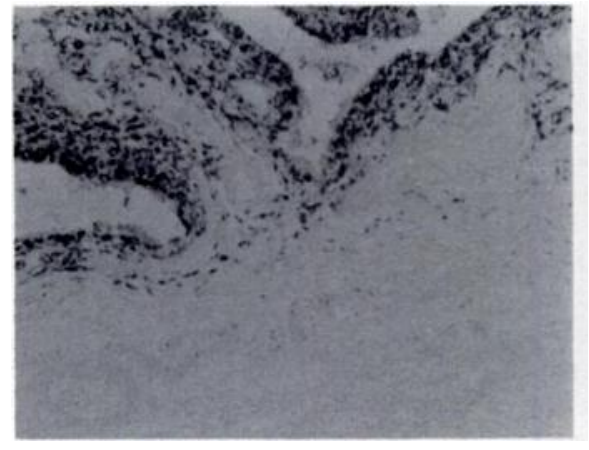

Fig. 1

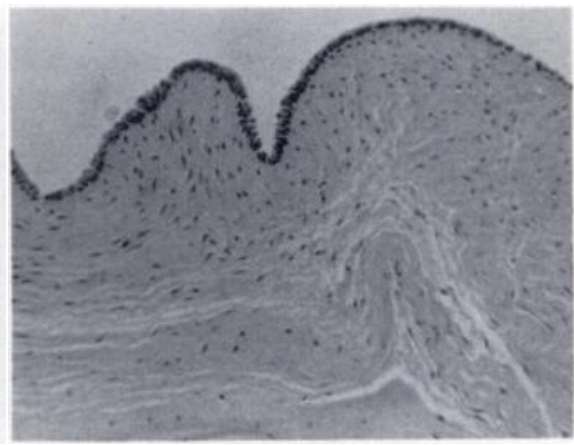

Fig. 2

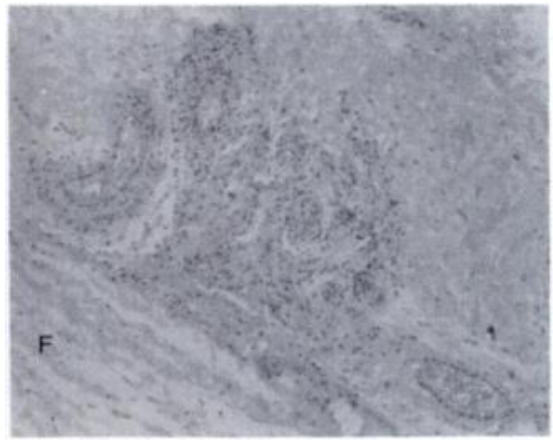

Fig. 3

Figure 1-Synovial membrane from the medial aspect of the knee of a 12-year-old haemophiliac. The proliferative villi contain abundant haemosiderin, in marked contrast to the adjacent subsynovial layer. The large number of subsynovial blood vessels is conspicuous (Perls' stain, $\times 40)$. Figure 2-Synovial membrane from the medial aspect of the knee of a 35-year-old haemophiliac with a long history of repeated haemarthroses into the joint. The layer lining the joint is intact and loaded with haemosiderin deposits, while the subsynovial layer is free of haemosiderin and shows advanced homogenous fibrosis (Perls' stain, $\times 10)$. Figure 3 -Inflammatory infiltrates surrounding deep-seated subsynovial vessels. $F$, fibrotic subsynovial layer (haematoxylin and eosin, $\times 16$ ). 


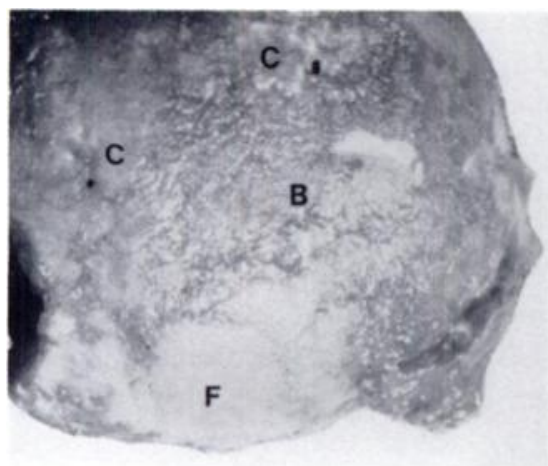

Fig. 4

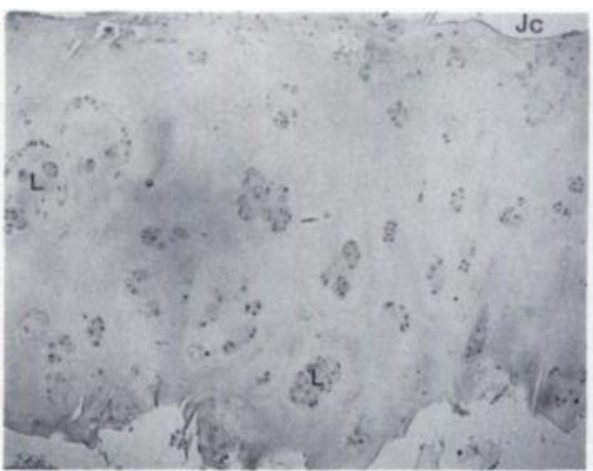

Fig. 5

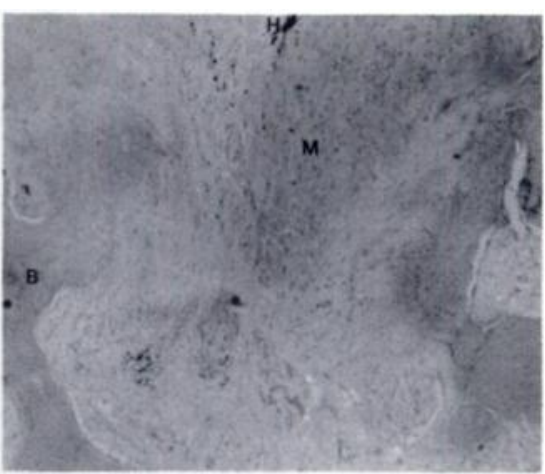

Fig. 6

Figure 4-An excised femoral head from a haemophiliac, showing advanced disintegration. $C$, vestiges of articular cartilage; $F$, repair fibrocartilage; $B$, eburnated bone. Figure 5-Articular cartilage from the knee of an adult haemophiliac. The cartilage is thin with a disrupted surface, marked fibrillation and formation of chondrocyte clusters $(L) ; J c$, joint cavity (haematoxylin and eosin, $\times 40$ ). Figure $6-$ Proliferating fibrous tissue from the subchondral marrow spaces invading and filling large defects in the articular cartilage. $B$, subchondral bone; $H$, haemosiderin granules in the matrix; $M$, hyaline metaplasia (haematoxylin and eosin, $\times 16$ ).

bone (Fig. 4). The remaining cartilage was thin and extensively damaged (Fig. 5). Its surface layer was uneven, and in places fragments of cartilage freely protruded into the joint cavity. Often, fine fissures and wider vertical clefts extended throughout the cartilage layers, well into the subchondral bone. Proliferating fibrous tissue arising in the marrow spaces of the subchondral bone frequently invaded the deep surface of these clefts (Fig. 6). Within this fibrous tissue, islands of hyaline metaplasia were present in some specimens.

In the superficial layer, lacunae had formed alongside chondrocytes with pyknotic nuclei. Some lacunae were extremely enlarged and filled with amorphous material. The total cellularity of the articular cartilage was markedly increased in some areas and decreased in others. Single cells, pairs of cells and sometimes cell clusters (Fig. 5) were dispersed in an uneven fashion throughout the matrix. In the fibrocartilage of repair, single cells were evenly distributed throughout the whole tissue. Connective tissue often covered and partially replaced the superficial layer of the original articular cartilage.

\section{Histochemistry}

Perls' stain for haemosiderin. In the synovial membrane, haemosiderin, manifested as dark blue granules, was mainly present in cells of the superficial layer (Fig. 1). In the articular cartilage, intracellular haemosiderin deposits were prominent in chondrocyte clusters situated in the superficial zone (Fig. 7), but there were no such deposits in the matrix. In fibrocartilage, on the other hand, haemosiderin was dispersed throughout the matrix (Fig. 6).

Alcian blue staining. In synovium, the glycosaminoglycans, demonstrated by a light blue-green colour, were localised to the walls of the blood vessels. A light degree of staining appeared in the subsynovial matrix, but none in the lining layer. There was no difference in the colour distribution between the $0.5 \mathrm{M}$ and $0.7 \mathrm{M}-\mathrm{MgCl}_{2}$ concentrations, although the latter gave a much paler staining.
In articular cartilage, the colour intensity was patchy in all biopsies. The edges of most clefts and fissures displayed very low intensity of staining. Around chondrocyte clusters, the colour was intense while the intercellular matrix showed a very poor uptake of colour in all specimens. The matrix of the fibrocartilage of repair stained uniformly pale blue.

Compared with controls, haemophilic cartilage showed the same general colour distribution, although it was less intense in each layer, the lightest stain always appearing in the intercellular matrix. A thin area of intense staining seen on the joint-lining surface of control specimens was consistently missing from haemophilic cartilage.

\section{Electron microscopy}

The synovial lining cells were both hypertrophic and hyperplastic. Cells, cell fragments and amorphous,

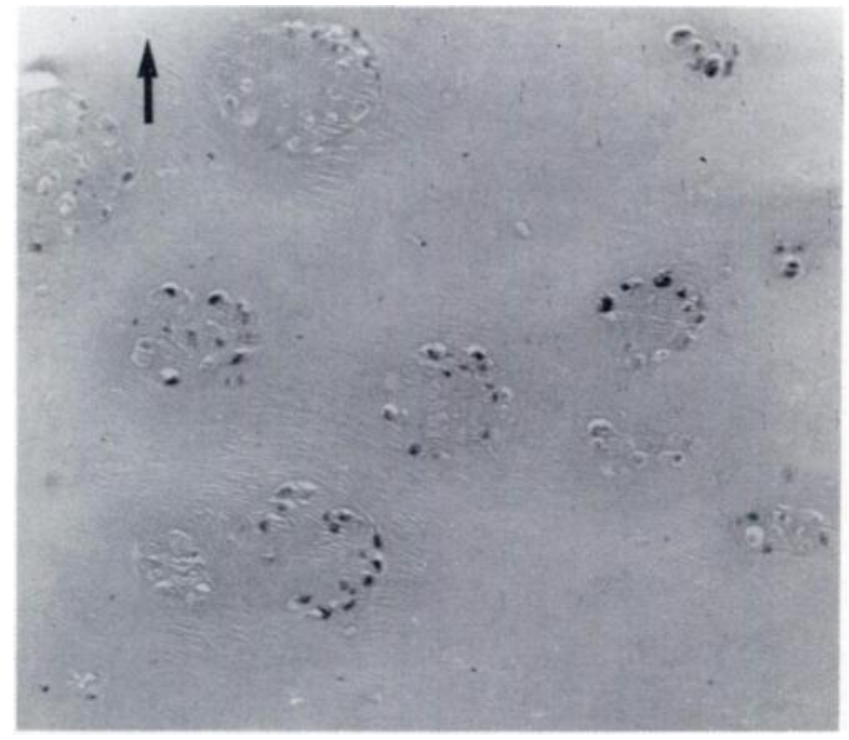

Fig. 7

Cell clusters in the superficial layer of articular cartilage from a haemophilic knee, showing intracellular haemosiderin deposits. Arrow points towards articular surface (Perls' stain, $\times 40$ ). 


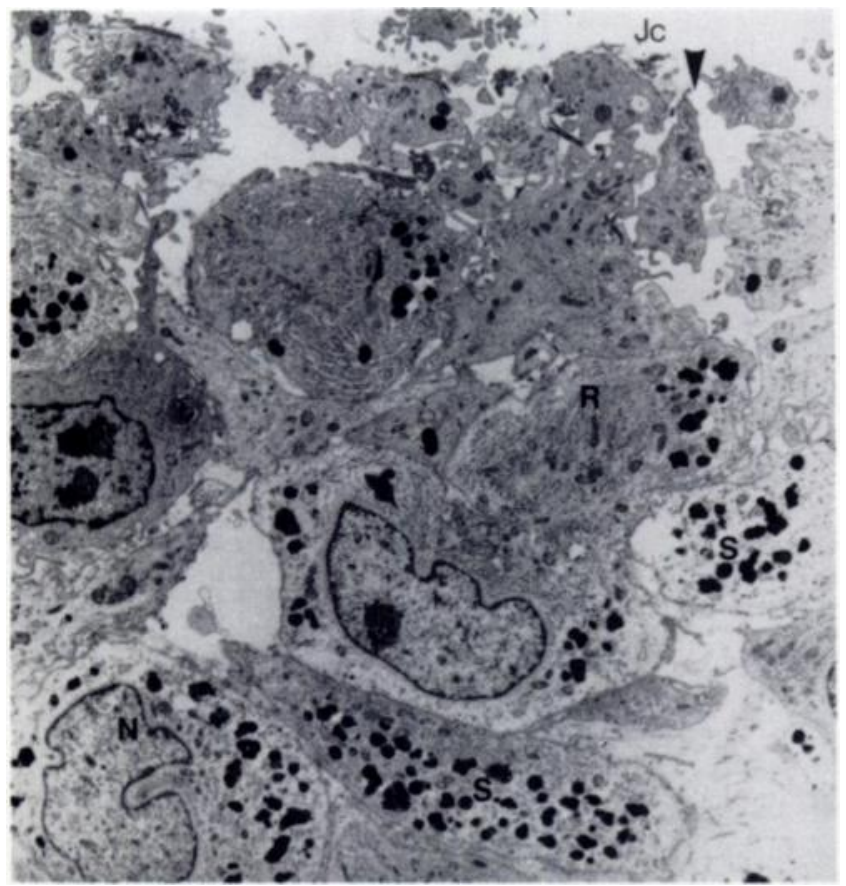

Fig. 8

Electron micrograph of haemophilic synovium. Cell and cell fragments from the lining layer with an arrow pointing to the gap between the fragments. Jc, joint cavity: $S$, siderosomes; $R$, endoplasmic reticulum: $N$, nucleus $(\times 4800)$.

ill-defined material between them were the constituents of this layer (Fig. 8). Most cells were closely packed, four to five deep, many of them having an elongated shape and marked cytoplasmic processes. Some of these cells were linked to their neighbours by what appeared to be a "tight junction" (Ghadially 1975).
Many cells displayed margination of chromatin in their nuclei and homogenisation of the nuclear content. Within their cytoplasm, electron-dense deposits were very common (Fig. 8). These deposits resembled the "siderosomes" described by Richter (1957, 1959). These particles varied in shape from single, small electron-dense bodies to complex, large, membranebound structures, incorporating a number of single siderosomes (Fig. 9). Mitochondria were seen near and between siderosomes in varying degrees of swelling, sometimes showing a loss of their cristae. All cells possessed a very prominent endoplasmic reticulum distinguished by vesiculation and dilatation. The Golgi complex was absent in some cells, and small and inconspicuous in others. Lysosomes were rare, but fine perinuclear, intracytoplasmic filaments were present in the majority of cells.

Thick bundles of collagen fibres filled the intercellular spaces of the subsynovial layer. The subsynovial blood vessels had a hyperplastic wall, made up of a large number of cells, with a desmosome type of junction.

The articular cartilage was considerably narrowed in height. On examination, the morphological architecture was so disrupted that often only the superficial zone could be identified with certainty. The chondrocytes of this zone were elongated, the nucleus having a regular form, with chromatin masses dispersed throughout. In the cytoplasm, signs of cell necrosis were often prominent. The mitochondria were "blown out" and filled with dense granules, while their cristae were distorted and frequently lost. The endoplasmic reticulum presented with a varying degree of cisternal

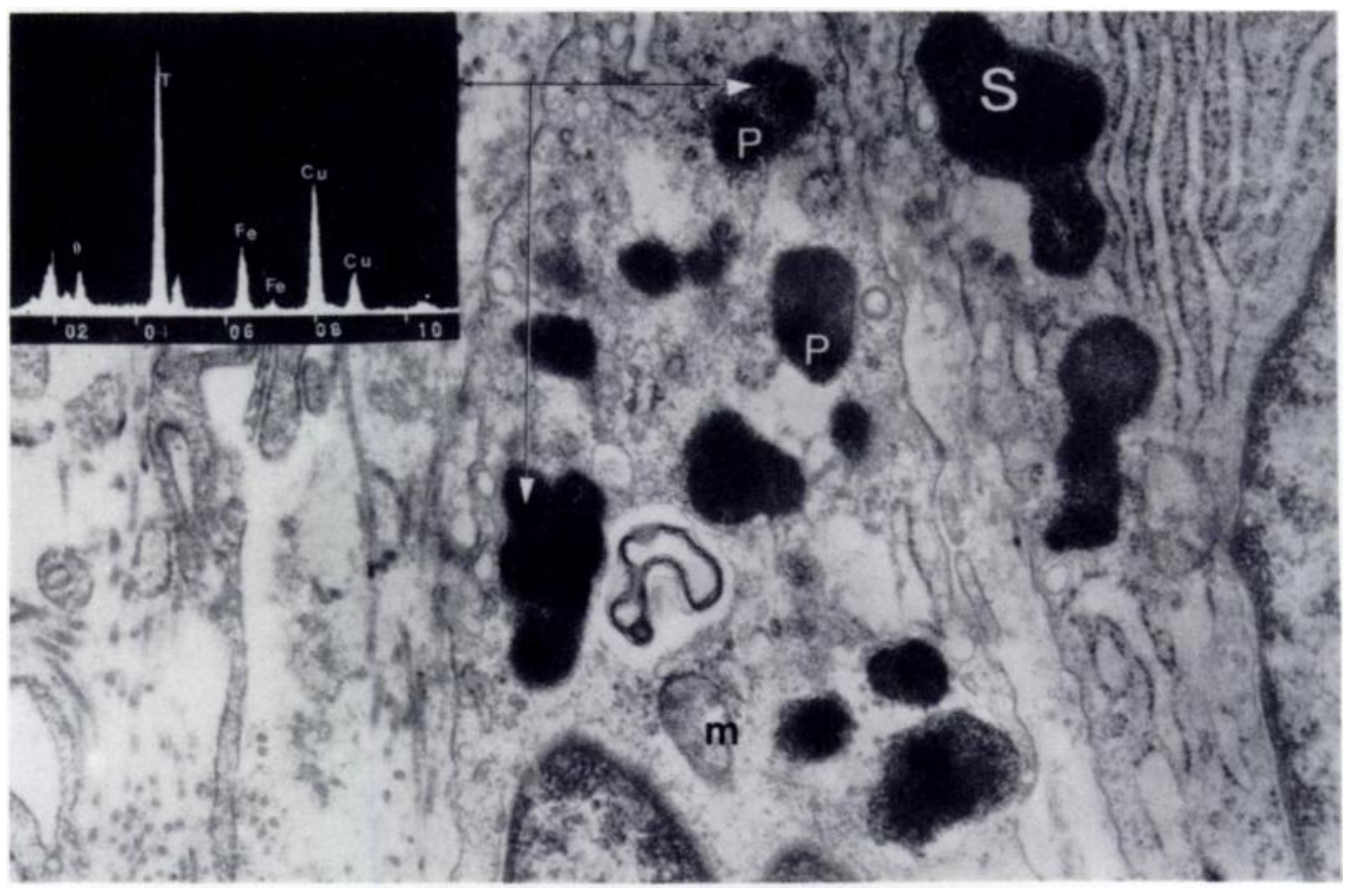

Fig. 9

Compound electron-micrograph of haemophilic synovium, showing iron-positive energy-dispersive analysis of electron-dense cytoplasmic bodies. Arrows point towards analysed deposits ( 40 seconds analysis time). $S$, true siderosome: $P$. eccentrically placed pseudonucleus: $m$, blown-out mitochondria with distorted cristae $(\times 21250)$. 
dilatation. Fine intracytoplasmic filaments were clearly located in the perinuclear areas. The intercellular spaces were filled with medium-sized collagen fibres running in all directions.

In what appeared to be the upper middle zone (Davies et al. 1962), only very few normal-looking chondrocytes were seen alongside cells which showed signs of necrosis. In the latter cells, the nuclear chromatin was "marginated", while the nuclear ground substance was entirely homogenous. The mitochondria were swollen or "blown-out"; the cisternae of the endoplasmic reticulum were dilated and vesiculated. The Golgi complex was often small and shrunken. In all these cells, electron-dense deposits were present (Fig. 10). The intercellular matrix contained many swollen collagen fibres, running predominantly obliquely to the surface.

\section{Microprobe analysis}

A variety of intracytoplasmic and intranuclear electron-dense bodies were analysed for iron. In the cytoplasm, many, but not all the electron-dense bodies contained iron. Iron-positive bodies were found in the cytoplasm of cells in the synovial lining layer (Figs 8 and 9) and in the chondrocytes of the articular cartilage (Fig. 10). Their shape was slightly oval, limited by an ill-defined membrane, apparently being a conglomerate of amorphous, electron-dense particles which contained an even denser eccentrically placed area, resembling a pseudonucleus. When the iron-positive cells were compared to the cell population of the same tissue which contained no iron deposits, it became obvious that all the iron-containing cells were in varying stages of necrosis and disintegration, while most of the iron-negative cells appeared viable. No iron-positive electron-dense deposits were detected in the matrix.

The microprobe analysis was performed in the two control groups. In the meniscectomy patients, iron deposits could not be demonstrated either in the synovial lining or in the subsynovial tissue. The patients affected by rheumatoid arthritis had iron deposits only deep in the subsynovial tissue. Whenever present, these deposits showed the morphology of the true siderosome.

\section{DISCUSSION}

The most common complication of haemophilia is crippling joint disease (Table III). The degeneration of a normal joint after recurrent bleeds is the result of a number of mechanisms which finally interact to produce severe distortion. The synovial lining becomes progressively more fibrotic, the hyaline cartilage disintegrates

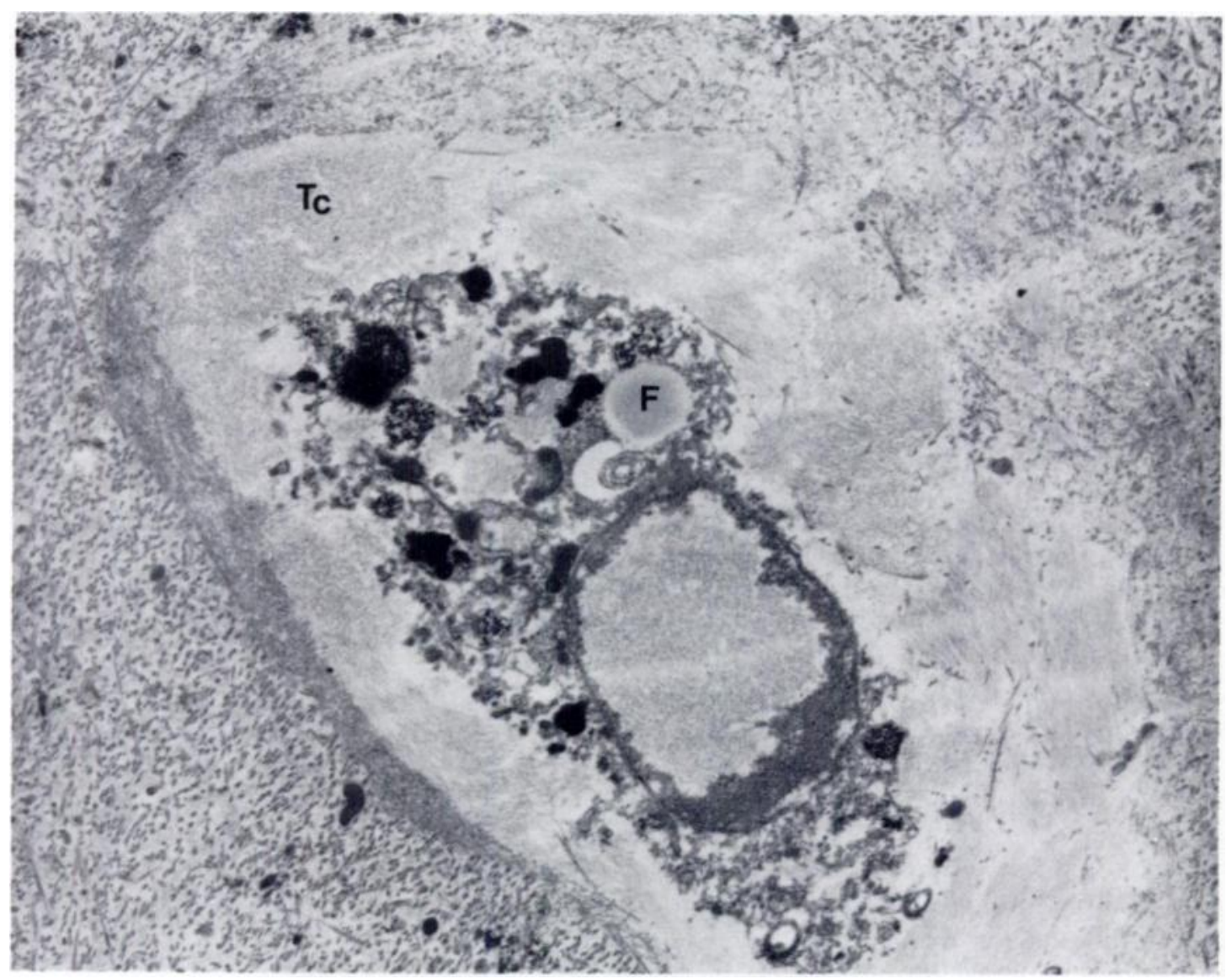

Fig. 10

Chondrocyte from the upper middle zone of haemophilic cartilage, showing advanced necrosis. The cytoplasm is loaded with true siderosomes and totally disrupted. $F$, fat accumulation in cytoplasm; $T c$, territorial capsule $(\times 10000)$. 
Table III. Incidence of chronic joint damage in haemophilic patients: review of the literature

\begin{tabular}{|c|c|c|c|}
\hline Author & Year & Number of patients & $\begin{array}{c}\text { Incidence of } \\
\text { joint damage } \\
\text { (per cent) }\end{array}$ \\
\hline Legg & 1872 & 5 & 60 \\
\hline Thomas & 1936 & 98 & 61.2 \\
\hline Birch & 1937 & 98 & 65.3 \\
\hline Ghormley and Clegg & 1948 & 76 & 58 \\
\hline Davidson et al. & 1949 & 40 & 95 \\
\hline Rodnan et al. & 1957 & 53 & 79.2 \\
\hline Webb and Dixon & 1960 & 42 & 53.4 \\
\hline Ali et al. & 1967 & 131 & 62.3 \\
\hline $\begin{array}{l}\text { Hough, Banfield and } \\
\text { Sokoloff }\end{array}$ & 1976 & $\begin{array}{l}\text { Estimated from total } \\
\text { US population }\end{array}$ & 80 \\
\hline
\end{tabular}

and finally is lost. Mechanical and chemical processes are involved but enzymatic processes appear to be primarily responsible for the degradation of the cartilage matrix. The findings of this study are discussed in relation to the mechanisms of progressive deterioration (Fig. 11).

The synovial membrane undergoes extensive fibrosis, scar tissue replacing the entire thickness including the lining layer. This loss of synovial cells affects the synthesis and secretion of glycosaminoglycans (Revel and Hay 1963) and the sections stained with alcian blue demonstrated these compounds only around the blood vessels. There is therefore a significant alteration in the physicochemical properties of the synovium. The mitochondria in haemophilic synovium are severely distorted, implying loss of their metabolic function in providing the main source of cellular adenosine triphosphate (Ghadially 1975). The absence of iron deposits within the cells in the lining layer of the joints of older patients suggests that scar tissue has replaced synovium.

The architecture of articular cartilage was severely disrupted. Chondrocytes were irregularly dispersed through the matrix and often aggregated in cell clusters as first described by Weichselbaum (1872). These are a proliferative reaction to damage (Seggel 1904; Reinecke and Wohlwill 1929; Collins and McElligott 1960; Guicciardi and Little 1967; Hulth, Lindberg and Telhag 1972; Rothwell and Bentley 1973; Thompson 1975; Stockwell and Meachim 1979). Dissolution of the matrix seems to be the stimulus for the formation of cell clusters (Sokoloff 1974). Fibrous tissue proliferates from the marrow spaces of the subchondral bone to fill the defects and may undergo metaplasia into fibrocartilage. This demonstrates that in the haemophilic joint subchondral bone is actively involved in healing, a sequence which has been suggested by Seggel (1904) and Guicciardi and Little (1967) for other types of arthritis. In articular cartilage the alcian blue stain revealed a marked reduction in glycosaminoglycan content, concentrations of this compound being mainly in the vicinity of cell clusters (Meachim 1964; Maroudas, Evans and Almeida 1973; Ficat and Maroudas 1975).

The pathogenesis of these morphological changes can be explained by a number of mechanisms acting independently. Mechanical effects may involve both synovium and articular cartilage. The perivascular infiltration of the subsynovium suggests that haemarthroses may start as intramural haemorrhages which may either remain small or may rupture into the joint cavity. This interpretation is supported by Swanton (1959). Haemarthroses may persist for some days, and the longer the duration the more extensive the soft-tissue fibrosis produced (König 1892; Freund 1925; De Palma and Cotler 1956; Rodnan et al. 1959; Hough, Banfield and Sokoloff 1976). In a normal knee at rest the intra-articular pressure is atmospheric (McCarty 1974); this becomes negative if the quadriceps are contracted but in the presence of haemarthroses negative pressure is absent while positive pressure may be caused by large effusions. This pressure could rise to the same order as that of intracapillary pressure (Freund 1925; Key 1932), and further interfere with tissue perfusion. The stiffness of the scar tissue would tend to increase the changes in intra-articular pressure especially in flexion (McCarty 1974).

Mechanical effects on articular cartilage produce

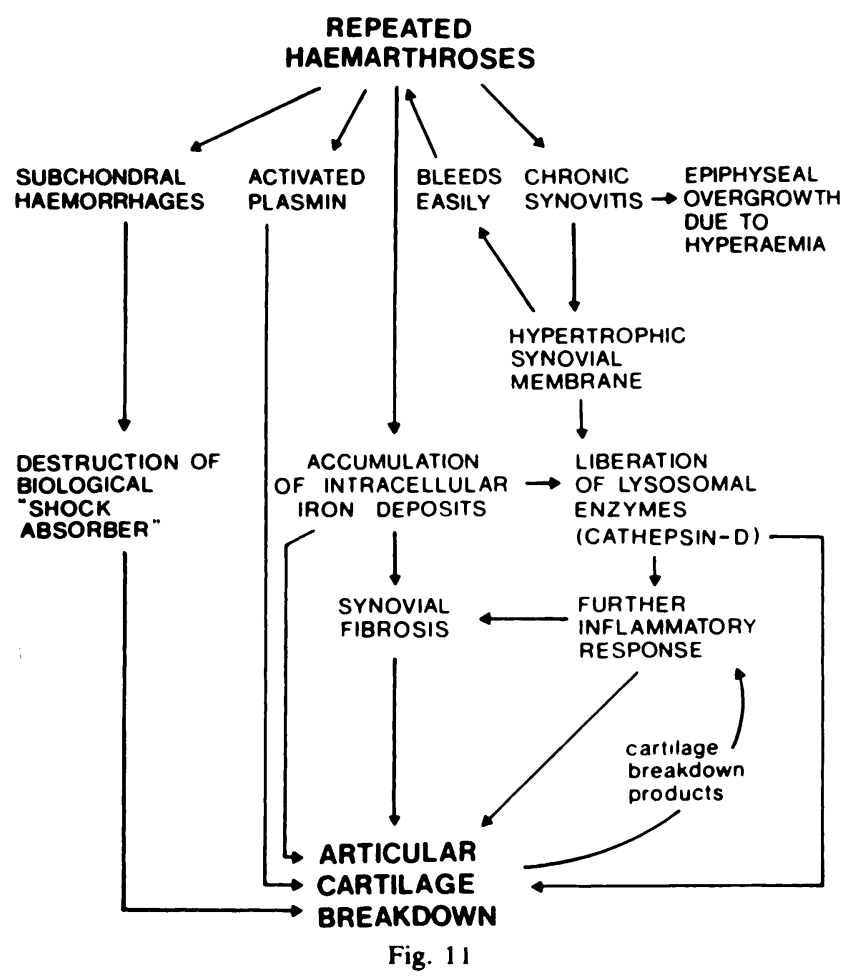

The pathogenesis of chronic haemophilic arthropathy. 
changes in the subchondral layer of bone which include loss of trabecular bone, cyst-like defects and even frank haematoma formation. This weakening reduces the ability of articular cartilage to withstand loading (Johnson 1962; Radin, Paul and Rose 1975). Articular cartilage is therefore exposed to abnormal pressure gradients while devoid of effective mechanical support. Another influence on articular cartilage is that of immobilisation which may occur in reaction to painful distension or as a method of treatment. Jaffe (1897) described frank fibrous ankylosis after immobilisation of joints and it is agreed that immobilisation reduces the amount of synovial fluid, resulting in loss of nutrients (Sigurdson 1930; Bywaters 1937; Maroudas 1968). Destruction of articular cartilage after long periods of immobilisation of the joint has been well documented (Roy 1970; Enneking and Horowitz 1972; Finsterbush and Friedman 1973; Troyer 1975; Langenskiöld, Michelsson and Videman 1979).

Chemical changes may also affect both the synovium and the articular cartilage. In the synovium villous proliferation and subsynovial hyperaemia were commonly found. Villi can be regarded as a proliferation of synovial cells (Braun 1894). In the subsynovial layer increased vascularity and inflammatory infiltrates around haemosiderin deposits were found. The hyperaemia has been defined (Sokoloff 1975) as a non-specific "angiomatoid" reaction. These changes indicate that the haemophiliac suffers from a chronic persistent synovitis which eventually destroys synovial tissue and leads to fibrous scarring.

The synovial cells themselves were rich in endoplasmic reticulum and fit the description of synovial B cells (Barland, Novikoff and Hamerman 1962). But the cells also contained electron-dense cytoplasmic deposits which on microprobe analysis were positive for iron. This would indicate either that synovial B cells have phagocytic properties, contrary to the theory of Barland et al. (1962), or that these cells are pluripotential and can alter their appearance according to functional requirements. This second possibility is supported by the findings of Wolcott (1927), Lever and Ford (1958), Andersen (1964), Schubert and Hamerman (1964) and Ghadially and Roy (1967). The morphology of the synovial cell may be altered by inflammation (Hamerman 1970) thus accounting for the abundance of intermediate cells in haemophilic synovium.

Microprobe analysis revealed that not all the electron-dense bodies were iron deposits. All cells containing true iron deposits showed degeneration and disintegration and this observation is corroborated by Soeur (1949), Adams (1966) and Schumacher (1972, $1973)$ in their studies of other arthropathies. It has been postulated by Richter $(1957,1959)$ that siderosomes, since they contain cristae, could be derivatives of mitochondria, although Hough et al. (1976) maintained that "evidence was lacking for the possibility that iron is deposited in mitochondria". Siderosomes are secondary lysosomes heavily loaded with indigestible debris and are also known as post-lysosomal or residual bodies, being devoid of enzymes (De Duve and Wattiaux 1966; Ghadially 1975). The lysosomal membrane of such secondary lysosomes could be damaged by direct chemical reaction in response to intracellular accumulation of iron. Similar change has been described in gout where uric acid crystals become linked to lysosomal membranes by hydrogen bonds, causing damage which allows the escape of hydrolytic enzymes (Weissmann 1971).

The chondrocytes of articular cartilage were loaded with intracellular iron deposits, proving their endocytotic properties. This has also been reported by Mankin (1974) and Oryschak and Ghadially (1974). Chondrocytes, like synovial cells, showed signs of necrosis after ingestion of iron. This would preclude adequate synthesis of glycosaminoglycans and collagen (Brighton, Bigley and Smolenski 1970) and thus make matrix degeneration inevitable. Mehta and Ghadially (1973) have shown that experimental lipoarthrosis can lead to phagocytosis and the necrosis of chondrocytes with loss of continuity and unevenness of the articular surface. Dingle suggested that intact cartilage matrix contains as yet unidentified substances which inhibit the endocytotic activity of chondrocytes (quoted by Stockwell 1974). It is possible that intracellular iron deposits may inhibit pyrophosphate enzyme activity and enhance calcium pyrophosphate precipitation in the form of cartilage calcification (Hamilton et al. 1968). Hough et al. (1976) have reported a marked reduction in collagen fibrils around the chondrocytes of haemophilic cartilage as well as the presence of vesicles in the matrix which resemble those occurring in calcifying epiphysial plate cartilage as a precursor of active mineralisation (Anderson 1969) and cartilage degeneration (Ali 1977; Stein, Bab and Sela 1981).

The most common pathway of destruction of the microstructures of the haemophilic joint may well be enzymatic effects. Cathepsin D is a proteolytic enzyme of lysosomal origin and has been identified in chick and rabbit cartilage (Woessner 1967) and at high levels in human haemophilic synovium and synovial fluid (Hilgartner 1973). Cathepsin has a marked chemotactic effect and is a potent hydrolytic enzyme thus perpetuating chronic inflammatory changes. It may induce the degradation of matrix and be instrumental in the development of degenerative changes.

Plasmin, which is produced by the activation of serum plasminogen, is a proteolytic enzyme derived from blood. It may be activated in synovial fluid by injury to the synovium and articular cartilage (Lack 1959, 1962; Lack and Ali 1967). The normal function of plasmin is the removal of fibrin, but when it is present in excess, as in joints that are often and repeatedly exposed to episodes of haemarthrosis, it may split the protein 
from the proteoglycan moeity of the cartilage matrix (Lack and Rogers 1958; Lack 1959).

It is suggested, therefore, that repeated haemarthroses lead to chronic synovitis with hypertrophic, easily damaged synovial membrane and subchondral haemorrhages (Fig. 11). The activation of plasmin and the release of cathepsin $\mathrm{D}$ following the accumulation of intracellular iron deposits leads to further inflammatory response and to continued breakdown of articular cartilage. This is accelerated by the loss of the support of subchondral bone and by further inflammatory response to mechanical and chemical damage.

\section{REFERENCES}

Adams WS. Fine structure of synovial membrane: phagocytosis of colloidal carbon from the joint cavity. Lab Invest 1966;15:680-91.

Ali AM, Gandy RH, Britten MJ, Dormandy KM. Joint haemorrhage in haemophilia: is full advantage taken of plasma therapy? Br Med $J$ $1967 ;$;iii:828-31.

Ali SY. Matrix vesicles and apatite nodules in arthritic cartilage. In: Willoughby DA, Giroud JP, Velo GP. eds. Inflammation. Future trends and developments. Lancaster: MTP Press, 1977:211-23.

Andersen H. Development, morphology and histochemistry of the early synovial tissue in human foetuses. Acta Anat 1964;58:90-115.

Anderson HC. Vesicles associated with calcification in the matrix of epiphyseal cartilage. $J$ Cell Biol 1969;41:59-72.

Barland P, Novikof AB, Hamerman D. Electron microscopy of the human synovial membrane. J Cell Biol 1962;14:207-20.

Birch CLF. Hemophilia. Clinical and genetic aspects. Univ Ill Bull. Ill Med Dent Monog 1937;1:(4).

Braun H. Untersuchungen über den Bau der Synovialmembranen und Gelenkknorpel, sowie über die Resorption flüssiger und fester Körper aus den Gelenkhöhlen. Dtsch Z Chir 1894;39:35-86.

Brighton CT, Bigley EC Jr, Smolenski BI. Iron induced arthritis in immature rabbits. Arthritis Rheum 1970;13:849-57.

Bulloch W, Fildes P. Treasury of human inheritance Vol. 1, Section XIVa Haemophilia. London: Dulau \& Co, 1912:169-354.

Bywaters EGL. The metabolism of joint tissues. J Pathol Bacteriol 1937;44:247-68.

Collins DH, McElligott TF. Sulphate (35SO4) uptake by chondrocytes in relation to histological changes in osteoarthritic human articular cartilage. Ann Rheum Dis 1960;19:318-30.

Coedett VE, Nixon WC. $X$-ray microscopy. Cambridge: University Press, 1960.

Davideon CS, Epotein RD, Miller GF, Taylor FHL. Hemophilia. A clinical study of forty patients. Blood 1949;4:97-119.

Davies DV, Barnett CH, Cochrane W, Palfrey AJ. Electron microscopy of articular cartilage in the young adult rabbit. Ann Rheum Dis. 1962;21:11-22.

De Duve C, Wattiaux R. Functions of lysosomes. Ann Rev Physiol 1966;28:435-92.

De Palma AF, Cotker JM. Hemophilic arthropathy. Arch Surg 1956;72:247-50.

Driessen APPM. Arthropathies in the haemophiliacs. Assen: van Gorcum \& Co, 1973.

Duthie RB, Rizza CR. Rheumatological manifestations of the haemophilias. Clin Rheum Dis 1975;1:53-93.

Enneking WF, Horowitz M. The intra-articular effects of immobilization on the human knee. J Bone Joint Surg [Am] 1972;54-A:973-85.

Ficat C, Maroudas A. Cartilage of the patella. Topographical variation of glycosaminoglycan content in normal and fibrillated tissue. Ann Rheum Dis 1975;34:515-9.

Finsterbush A, Friedman B. Early changes in immobilised rabbit knee joints. Clin Orthop 1973;92:305-19.

Freund E. Die Gelenkerkrankung der Bluter. Virchows Arch (Pathol Anat) 1925;256:158-88.

Ghadially FN, Roy S. Histochemistry of synovium in experimental haemarthrosis in the rabbit. Ann Rheum Dis 1967;26:117-22.

Ghadially FN. Ultrastructural pathology of the cell. London: Butterworths, 1975.

Ghormley RK, Clegg RS. Bone and joint changes in hemophilia. J Bone Joint Surg [Am] 1948;30-A:589-600.

Guicciardi E, Little K. Some observations on the effects of blood and a fibrinolytic enzyme on articular cartilage in the rabbit.J Bone Joint Surg $[B r]$ 1967;49-B:342-50.

Hamerman D. Synovial joints. Aspects of structure and function. In: Balazs EA, ed. Chemistry and molecular biology of the intercellular matrix. London: Academic Press, 1970;3:1259-72.

Hamilton E, Williams R, Barlow KA, Smith PM. The arthropathy of idiopathic haemochromatosis. J Med 1968;NS37:171-82.

Hilgartner MW. Pathogenesis of joint changes in hemophilia. In: McCollough NC, ed. Comprehensive management of musculo-skeletal disorder in hemophilia. Washington DC: National Academy of Sciences, 1973:33-6.

Hoaglund FT. Experimental hemarthrosis. J Bone Joint Surg [Am] 1967;49-A:285-98.

Hough AJ, Banfield WG, Sokolof L. Cartilage in hemophilic arthropathy. Arch Pathol 1976;100:91-6.

Huth A, Lindberg L, Telhag H. Mitosis in human osteoarthritic cartilage. Clin Orthop 1972;84:197-9.

Jafie A. Ueber die Veränderungen der Synovialmembran bei Berührung mit Blut. Arch Klin Chir 1897;54:69-97.

Johnson LC. Joint remodeling as the basis of osteoarthritis. J Am Vet Med Assoc 1962;141:1237-41.

Key JA. Hemophilic arthritis. Ann Surg 1932;95:198-225.

König F. Die Gelenkerkrankungen bei Blutern mit besonderer Berücksichtigung der Diagnose. Samml Klin Vortr Chir 1892;11:233-42.

Lack CH, Rogers HJ. Action of plasmin on cartilage. Nature 1958;182:948-9.

Lack CH. Chondrolysis in arthritis. J Bone Joint Surg [Br] 1959;41-B:384-7.

Lack CH. Increased vascular permeability, chondrolysis and cortisone. Proc Roy Soc Med 1962;55:113-6.

Lack CH, Ali SY. The degradation of cartilage by enzymes. In: Bassett CAL, ed. Cartilage degradation and repair. Washington DC: National Academy of Engineering, 1967:61-71

Langenskiöld A, Michelsson J-E, Videman T. Osteoarthritis of the knee in the rabbit, produced by immobilisation. Acta Orthop Scand 1979;50:1-14

Legs JW. A treatise on haemophilia, sometimes called the hereditary haemorrhagic diathesis. London: HK Lewis, 1872.

Lever JD, Ford EHR. Histological, histochemical and electron microscopic observation on synovial membrane. Anat Rec 1958;132:525-39.

Mankin HJ. The reaction of articular cartilage to injury and osteoarthrosis. $N$ Engl J Med 1974;291:1285-92 (part I) and $1335-40$ (part II).

Maroudas A. Physicochemical properties of cartilage in the light of ion exchange theory. Biophys $J$ 1968;8:575-95.

Maroudas A, Evans H, Almeida L, Cartilage of the hip joint. Ann Rheum Dis 1973;32:1-9.

McCarty DJ. Selected aspects of synovial membrane physiology. Arthritis Rheum 1974;17:289-96.

Meachim G. Sulphate metabolism of articular cartilage after surgical interference with the joint. Ann Rheum Dis 1964;23:372-80. 
Mehta PN, Ghadially FN. Articular cartilage in corn oil-induced lipoarthrosis. Ann Rheum Dis 1973;32:75-82.

Oryschak AF, Ghadially FN. Aurosomes in rabbit articular cartilage. Virchows Archiv (Cell Pathol) 1974;17:159-68.

Radin EL, Paul IL, Rose RM. Mechanical factors in the aetiology of osteoarthrosis. Ann Rheum Dis 1975;34 suppl 2:132-3.

Reinecke H, Wohlwill F. Über hämophilie Gelenkerkrankung. Langenbecks Arch Klin Chir 1929;154:425-79.

Revel J-P, Hay ED. An autoradiographic and electron microscopic study of collagen synthesis in differentiating cartilage. $Z$ Zellforsch 1963;61:110-44.

Richter GW. A study of hemosiderosis with the aid of electron microscopy. $J$ Exp Med 1957;106:203-17.

Richter GW. The cellular transformation of injected colloidal iron complexes into ferritin and hemosiderin in experimental animals. $J$ Exp Med 1959;109:197-216.

Rodnan GP, Lewis JH, Warren JE, Brower TD. Hemophilic arthritis. Bull Rheum Dis 1957;8:137-8.

Rodnan GP, Brower TD, Hellstrom HR, Didisheim P, Lewis JH. Postmortem examination of an elderly severe hemophiliac, with observations on the pathologic findings in hemophilic joint disease. Arthritis Rheum 1959;2:152-61.

Rothwell AG, Bentley G. Chondrocyte multiplication in osteoarthritic articular cartilage. J Bone Joint Surg [Br] 1973;55-B:588-94.

Roy S. Ultrastructure of articular cartilage in experimental immobilisation. Ann Rheum Dis 1970;29:634-42.

Schubert M, Hamerman D. The functioning of the diffuse macromolecules of joints. Bull Rheum Dis 1964;14:345-8.

Schumacher HR. Distribution of carbon after intravenous injection in the normal rabbit: leakage into the synovium but not other non-reticuloendothelial tissues. Experientia 1972;28:1207.

Schumacher HR. Fate of particulate material arriving at the synovium via the circulation. Ann Rheum Dis 1973;32:212-8.

Seggel R. Experimentelle Beiträge zur Anatomie und Pathologie des Gelenkknorpels. II Studien über Knorpelwunden und Defekte. Dtsch Z Chir 1904;75:453-66.

Sigurdson LA. The structure and function of articular synovial membranes. J Bone Joint Surg 1930;12:603-39.

Soeur R. The synovial membrane of the knee in pathological conditions. J Bone Joint Surg [Am] 1949;31-A:317-40.

Sokoloff L. The general pathology of osteoarthritis. In: Ali SY, Elves MW, Leaback DH, eds. Normal and osteoarthritic articular cartilage. London: The Institute of Orthopaedics 1974:111-23.

Sokoloff L. Biochemical and physiological aspects of degenerative joint diseases with special reference to hemophilic arthropathy. Ann NY Acad Sci $1975 ; 240: 285-90$.

Stein H, Yarom R, Robin GC, Peters PD, Hall TA, Makin M. Spread of gold injected into the joints of healthy rabbits. J Bone Joint Surg [Br] 1976;58-B:496-503.

Stein H, Bab J, Sela J. The occurrence of hydroxyapatite crystals in extracellular matrix vesicles after surgical manipulations in the rabbit knee joint. Cell Tiss Res 1981;214:449-54.

Stockwell RA, Meachim G. The chondrocytes. In: Freeman MAR, ed. Adult articular cartilage. 2nd ed. London: Pitman Medical, 1979:69-144.

Stockwell RA. Cellular aspects: the chondrocyte population and the chondrocyte. In: Ali SY, Elves MW, Leaback DH, eds. Normal and osteoarthritic articular cartilage. London: The Institute of Orthopaedics, 1974:9-18.

Swanton MG. Hemophilic arthropathy in dogs. Lab Invest 1959;8:1269-77.

Thomas HB. Some orthopaedic findings in ninety-eight cases of hemophilia. J Bone Joint Surg 1936;18:140-7.

Thompson RC Jr. An experimental study of surface injury to articular cartilage and enzyme responses within the joint. Clin Orthop 1975;107:239-48.

Troyer H. The effect of short-term immobilisation on the rabbit knee joint cartilage. Clin Orthop 1975;107:249-57.

Webb JB, Dixon A StJ. Haemophilia and haemophilic arthropathy.. Ann Rheum Dis 1960;19:143-57.

Weichselbaum A. Arthritis deformans der beiden Schulter und Ellbogengelenke und des linken Hüftgelenks. Virchows Arch (Pathol Anat) 1872;55:217-28.

Weissman G. The molecular basis of acute gout. Hosp Practice 1971;6:43-52.

Woessner JF Jr. Acid cathepsins of cartilage. In: Bassett CAL, ed. Cartilage degradation and repair. Washington DC: National Academy of Engineering, 1967:99-106.

Wolcott WE. Regeneration of the synovial membrane following typical synovectomy. J Bone Joint Surg 1927;9:67-78. 